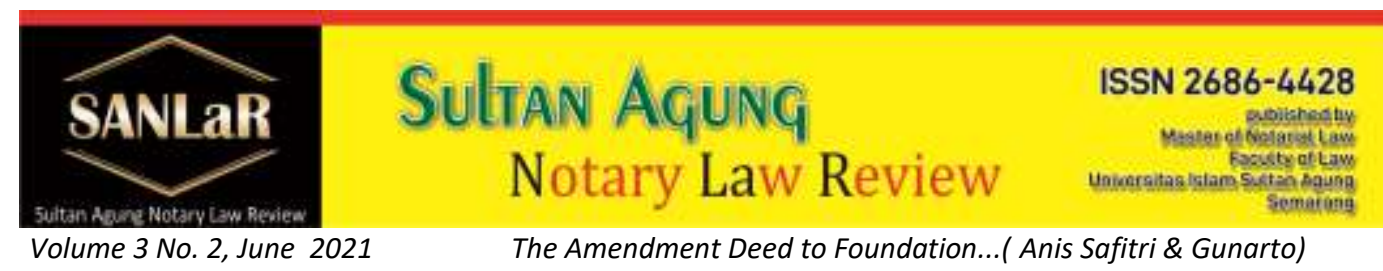

\title{
The Amendment Deed to Foundation Budget through Notary on Foundation's Assets from Waqf Process
}

\author{
Anis Safitri ${ }^{*}$ and Gunarto**) \\ ${ }^{*}$ Faculty of Law, Universitas Islam Sultan Agung (UNISSULA) Semarang, E-mail: \\ aanniissaa27@gmail.com \\ ${ }^{*}$ ) Faculty of Law, Universitas Islam Sultan Agung (UNISSULA) Semarang, E-mail: \\ gunarto@unissula.ac.id
}

\begin{abstract}
The establishment of a Foundation after the enactment of Act No. 28 of 2004 concerning Amendments to Law of the Republic of Indonesia Number 16 of 2001 concerning Foundations is carried out with the condition that there are founders, a Notary Deed and obtain legal entity status which after the deed of establishment obtains approval from the Minister of Justice and Human Rights or appointed officials. Along the way, the foundation can also experience changes. Amendments may include amendments to the articles of association, except for the purposes and objectives. The purpose of this journal research is one, to analyze the legal review of the position of the deed of amendment to the foundation's articles of association through a notary on the foundation's assets from the waqf process. two, to analyze the obstacles and solutions for changing the foundation's articles of association through a notary on the foundation's assets from the waqf process. The approach method in this legal journal research is to use normative legal research with a sociological juridical approach and other approaches including case approach, statute approach, historical approach, comparative approach, Conceptual approach (conceptual approach) . the results of this study indicate the obstacles and solutions for changing the foundation's articles of association through a notary on the foundation's assets from the waqf process is a legal consequence of the notary's error in making a deed of amendment to the articles of association with the intention of adjusting the foundation's articles of association with the foundation law, if any parties who feel aggrieved and there are those who file a notary lawsuit can be sued to pay compensation, interest and fees. And the notarial deed has no legal force if it is not in accordance with the laws and regulations that apply to the foundation.
\end{abstract}

Keywords: Waqf Foundation; Amendment Deed; Waqf; Notary. 


\section{Introduction}

Foundations in Indonesia are generally engaged in the health, education, social, religious and cultural fields. Foundations engaged in education are very often found, then there are also foundations engaged in the health sector, for example, establishing hospitals in the regions or in strategic areas. Foundations engaged in social activities such as establishing orphanages, caring for disabled children as well as their education, caring for the elderly, babysitting, establishing a rehabilitation center for narcotics sufferers and unemployed people lost, and so on. ${ }^{1}$

Prior to the enactment of Act No. 16 of 2001 concerning Foundations, the establishment of foundations in Indonesia at that time was only based on the customs in society, the jurisprudence of the Supreme Court and the opinion of experts (doctrine). Because there are no clear rules regarding the establishment of a foundation, the establishment of a foundation can be done freely, which means it can be made with a Notary Deed or an underhand deed. Therefore, in the absence of clear regulations governing the Foundation, various problems arise, both problems relating to disputes between the Management and the Founder and/or other parties,

Departing from the examples of the problems mentioned above where the Government has the intention to provide a correct understanding to the public regarding foundations, ensure legal certainty and order and restore the position, function of foundation organs as legal institutions, Act No. 16 of 2001 concerning Foundations was born and then followed by with Act No. 28 of 2004 concerning Amendments to Act No. 16 of 2001 concerning Foundations.

After the enactment of Act No. 28 of 2004 concerning Amendments to Law of the Republic of Indonesia Number 16 of 2001 concerning Foundations, Foundations are recognized as private legal entities whose existence is recognized as independent legal subjects. In addition, with the existence of positive law in written rules, namely the Act, it provides a juridical basis for the development of Foundations in Indonesia. Along with the enactment of the Law, various requirements regarding foundations emerged, one of which is that a foundation can be said to be a legal entity if it has complied with and/or adjusted its articles of association in accordance with the Law that has been determined.

\footnotetext{
${ }^{1}$ Murni \& Abdul Gani. (2020). "Tanggung Jawab Hukum Kepada Pengurus Yayasan Terhadap Failednya Suatu Yayasan”. dalam Jurnal Pionir LPPM Universitas Asahan Vol. 6 No. 1 (2020), http://jurnal.una.ac.id/index.php/pionir/article/view/1057, accessed November 16, 2020 at 21.50 WIB
} 
Based on the things mentioned above, the problems related to this research with the formulation of the problem are: how is the case of the legal review position of the deed of amendment to the foundation's articles of association through a notary on the foundation's assets from the waqf process and how are the obstacles and solutions for changing the foundation's articles of association through a notary on the assets of the foundation from the waqf process.

\section{Research Methods}

The approach method in this legal research is a sociological juridical approach with approaches including case approach, statute approach, historical approach, comparative approach, conceptual approach ${ }^{2} \mathrm{This}$ approach is carried out by reviewing all laws and regulations related to the problems (legal issues) that are being faced. ${ }^{3}$ The purpose of this study is to find out the legal review of the case of the position of the amendment to the foundation's articles of association through a notary on the foundation's assets from the waqf process. to find out how to make a deed of amendment to the foundation's articles of association through a notary on the foundation's assets from the waqf process. to find out how the obstacles and solutions are changing the foundation's articles of association through a notary on the foundation's assets from the waqf process.

\section{Result and Discussion}

\subsection{Case of Position Legal Review Deed of Amendment to Foundation Articles of Association through Notary on Foundation Assets from Waqf Process}

The development of Foundations in Indonesia was accompanied by the emergence of various disputes regarding changes to the Foundation's Articles of Association, especially in the aims and objectives of the Foundation. One example is RSI YARSIS where the main object of the dispute is the Deed of Amendment to the Foundation's Articles of Association.

The foundation was established with the Deed of Establishment Number 35 of 1970 drawn up before a notary R. Soegondo Notodisoerdjo where in article 2 the aims and objectives of the Foundation are as follows:

a. Establishing/building and running Islamic Hospitals and other businesses in the health sector (Medical Centers, Maternal and Child Health Centers, Pharmacies, Drug Manufacturers and others);

\footnotetext{
${ }^{2}$ Soekanto,Soejono.(2010). “Pengantar Penelitian Hukum”, Jakarta : UI Press, p. 6.

${ }^{3}$ Marzuki,Peter Mahmud. (2006). "Penelitian Hukum, Second Edition". Jakarta: Kencana Prenada Media Group, p.93.
} 
b. For the first time a hospital will be established with the highest level of care and in accordance with Islamic teachings for the sick community in general with respect to class, religion and position;

c. Organizing a place for education for cadres in the field of health with a true Islamic spirit (doctors, nurses, midwives, and so on);

It is also stated in the deed of establishment that the foundation was established with the initial assets originating from the Waqf of the founders and the Muslim community in Surakarta. Over time, the Waqf Foundation made adjustments to Act No. 28 of 2004 concerning Amendments to Act No. 16 of 2001 concerning Foundations. Which then made several changes, the first change was contained in Deed Number 02 dated September 17, 2011 made by a Notary in Surakarta, where in the Deed specifically changed Article 3 paragraph (1) regarding activities to achieve the aims and objectives of the Waqf Foundation to become following :

a. Establish/build and manage and/or run Hospitals, Medical Centers, Maternal and Child Health Centers, Maternity Clinics, Laboratories;

b. Establish other activities related to the hospital;

In this dispute, one of the founders feels aggrieved regarding the Deed of Amendment to the Foundation as contained in the Deed No. 02 dated 17 September 2011 made by a Notary in Surakarta. Where the founders of the Waqf Foundation felt that the Amendment to the Articles of Association had deviated and or violated the noble ideals of the Founders because the amendments to the Articles of Association in the aims and objectives of the foundation removed the name "Surakarta Islamic Hospital" to just "Hospital" and omitted the sentence " according to Islamic teachings. The foundation established a hospital based on Islam which later became the assets of the Waqf Foundation.

Referring to article 1 lift 7 of Act No. 2 of 2014 concerning Amendments to Act No. 30 of 2004 concerning the Position of a Notary that the Deed drawn up by or before a Notary is domiciled as an Authentic Deed according to the form and procedures stipulated by the Act Notary position. The main basis in making a Notary Deed is the will and request of the parties, where the wishes and requests of the parties are poured out by the Notary into a Deed. In order to fulfill the wishes and requests of the parties, the Notary can provide suggestions while still being guided by the applicable laws.

Thus, the object of dispute made by the Notary with all its derivatives regarding changes to the articles of association arising from the object of the dispute, both in the form of a Deed and all decisions that are organizational and administrative in nature as well as formal legal ones that have been issued based on the deed of the object of the dispute are legally flawed and do not have any legal rights. 
Because the Notary is the party that issues the object of the dispute, the Notary is obliged to submit and obey the legal process in this case until it has permanent legal force, so as not to cause new legal conflicts.

\subsection{Barriers and Solutions to Changes in Foundation Articles of Association through a Notary for Foundation Assets from the Waqf Process}

A Notary in carrying out his position must be responsible both in terms of authority and obligations, meaning: ${ }^{4}$

a. Notaries are required to make the deed properly and correctly, meaning that the deed made must fulfill the legal will and the request of the interested parties.

b. Notaries are required to produce a quality deed, meaning a deed made in accordance with the rule of law and the will of the interested parties in the true sense, not making it up and must be able to explain to the interested parties the truth of the contents and procedures of the deed he made.

c. It can have a positive impact on anyone, especially the parties who have an impact on the recognition of the deed having perfect proof power.

The notary has material and formal responsibility for the deed made, regarding his formal responsibility, namely being responsible for the validity of the authentic deed he made and if it turns out that there is a legal defect, the deed can lose its authenticity and harm interested parties. Meanwhile, regarding material responsibility for the deed made before a Notary, it is necessary to emphasize that with the authority of a Notary in making an Authentic Deed, it does not mean that the Notary can freely according to his will make an Authentic Deed without the parties requesting the Deed to be made. The elements that must exist in the making of a Notary Deed are as follows: ${ }^{5}$
a. Elements of Clarity
b. Elements of Equipment
c. Elements of Truth
d. Elements of Validity

The notary is only limited to guaranteeing that the appearer is correct in speaking such words, but there is no possibility of the notary being able to

\footnotetext{
${ }^{4}$ Azrani, Nur. (2010). "Peranan Notaris Terhadap Perubahan Anggaran Dasar Yayasan yang Berbadan Hukum Setelah Undang-Undang Nomor 28 Tahun 2004 Tentang Yayasan Di Tanjung Pinang Kepulauan Riau". Post-Graduate Program Universitas Gadjah Mada Yogyakarta. ${ }^{5}$ Mulyoto. (2012). "Perjanjian (Teknik, Cara Membuat, dan Hukum Perjanjian)". Yogyakarta : Cakrawala Media, p. 25-26.
} 
guarantee that what is said/stated by the appearer is true (based on the applicable legal provisions) unless the notary concerned understands or has understood the regulations, in relation to concrete cases related with what will be made.

The establishment of foundations in Indonesia so far has only been based on the prevailing custom in the community, namely by establishing it with a notarial deed and registered with the District Court whose jurisdiction covers the domicile of the foundation, if the founder of the foundation considers it necessary to register it. Foundation establishment is based on jurisprudence and customary law that exists in society, in general people agree that since its establishment a foundation has attached its legal entity status.

Whereas the position of the Foundation in the Indonesian legal system, the foundation is a legal identity whose existence in legal traffic in Indonesia has been recognized by the Indonesian people. Based on customary law and legal assumptions that apply to the general public, the characteristics of a foundation as a legal identity can be stated as follows:

a. The existence of a foundation as a legal identity in Indonesia has not been based on the applicable laws and regulations.

b. The recognition of foundations as legal entities does not yet have a firm juridical basis as is the case with companies, cooperatives and other legal entities.

c. Foundations are formed with personal wealth for non-profit purposes, for religious, social, religious, humanitarian and other charitable purposes.

d. The foundation is established by a notarial deed or by a decree of the official concerned with the establishment of the foundation.

e. The foundation does not have members and is not owned by anyone, but has management or people to realize the foundation's goals.

$\mathrm{f}$. The foundation has an independent position, as a result of the existence of assets separate from the personal assets of the founder or administrator and has its own purpose different from or independent of the personal goals of the founder or administrator.

g. The foundation is recognized as a legal entity as well as a person, which means that he is recognized as an independent legal subject who can carry independent rights and obligations, is established by deed and registered at the local Court Registrar's office.

Even though a foundation as a legal entity is a legal creation, it can be interpreted as an artificial person (artificial person), however a foundation is truly an independent legal subject which is provided by law with rights and obligations that are no different from the rights and obligations of a person. Because foundations are subject to self-immolation, their existence does not 
depend on the existence of members of the Trustees, Management, and Supervisors.

Even though they changed, the change did not change the existence of the foundation as a "persona standi in judicio". Unlike the case with the legal status of the association as a civil legal entity which has clearly been regulated in Staatsblad 1870 No. 64 concerning "Rechtspersoonlijkheid van Vereenigingen", the recognition of the Foundation as a legal entity as described above is solely a product of jurisprudence so that the existence of a foundation as a legal entity is difficult to be identified juridically.

The role of the Notary Public is based on the implementation of the deed of establishment of the foundation based on Act No. 28 of 2004 concerning Foundations, namely:

a. Explaining the conditions for the formation of children for the establishment of the foundation to the founders of the foundation;

b. Prepare (pour) the deed of establishment;

c. Apply for approval to the Minister of Law and Human Rights.

Notary deed made by/ before a Notary related to violations or contrary to the provisions of the Act or Government Regulations in relation to the applicable Foundation. Such deeds can be divided into:

a. Notarial Deed relating to the Foundation is null and void by law.

b. The Notary Deed relating to the Foundation can be requested for cancellation of the Notary Deed which is null and void and can be requested for cancellation.

In practice, both of them must be formally asked to the Court to decide which leads to the Authorized Deed (including the Deeds relating to the Foundation) to have no evidentiary power and do not bind anyone or any party, who has the authority to apply to the Court so that the Deed - The Notary Deed is canceled is the party who feels aggrieved by the issuance of the Notary Deed. Notary deed in relation to Foundations that violate or contradict the Law and or Government Regulation regarding Foundations should rationally request for cancellation to the Minister of Law and Human Rights of the Republic of Indonesia (in the past the Minister of Justice of the Republic of Indonesia) as the authorized official (who ratifies, approves or receives notification) of the deed - the said notarial deed.

The legal consequence of a Notary deed that the deed of amendment to the Articles of Association and Adjustments is made not in accordance with the Law or Government Regulation concerning Foundations is not limited to making an 
adjustment deed, but a new deed of establishment is made so that the deed does not base on Article 37 of Government Regulation Number 63 of 2008 concerning implementation Foundation Act. If the Notary in making the adjustment deed in relation to the Foundation has implemented the provisions applicable to the foundation, there will be no multiple interpretations nor the old position of the foundation will not be lost due to the existence of a new deed of establishment.

Whereas the legal consequence is that a Notary can be sued to pay compensation, interest and fees as a result of the Foundation's Management being harmed, namely the loss of the Foundation's assets which actually belong to the Foundation, then the Notary is reported to the Regional Supervisory Council of the Indonesian Notary Association, the Regional Supervisory Council of the Indonesian Notary Association and The Honorary Council of the Indonesian Notary Association for violating Article 15 paragraph (2) letter e for not being thorough, incompetent and unprofessional, and having made a deed that was not based on the applicable legal provisions.

Compensation that can be imposed on a Notary, among others, is as follows:

\section{Compensation based on the Civil Code}

The relationship between the notary and the appearers cannot be ascertained or determined at the beginning when the notary and the appearers communicate (in contact), because at that time there has not been any problem. To determine the form of legal relationship between the Notary and the appearers, it must be related to the provisions of Article 1869 of the Civil Code that authentic deeds are degraded into proof of power as underhanded deeds for the following reasons:

a. Not authorized by the public official concerned or;

b. Not having the ability of the Public Official concerned in making the deed;

c. Defects in their form, however, such a deed still has the power of proof as an underhand deed if the deed is signed by the parties.

This can be used as the basis for suing the Notary as an act against the law. The forms of compensation for unlawful acts known by law are nominal compensation, compensation compensation and anti-punitive damages. According to the Civil Code, the provision regarding compensation due to an act against the law is not much different from compensation due to a breach of contract.

2. Compensation according to the Law on Notary Positions 
The compensation referred to in the law on the position of a Notary consists of administrative sanctions and civil sanctions. Administrative sanctions are regulated in Article 7, Article 11, Article 13, Article 16, Article 17, Article 19, Article 32, Article 54 and Article 65 A of Act No. 2 of 2014. These administrative sanctions are in the form of a written warning, temporary dismissal, dismissal with respect and dishonorable discharge.

\section{Closing}

The legal review of the case of the position of the Deed of Amendment to the Foundation's Articles of Association through a Notary on Foundation Assets From the Waqf Process is that the Notary implementing the amendment to the Foundation's Articles of Association violates a rule that essentially prohibits changes to the aims and objectives of the foundation, moreover the position of the Foundation as a Waqf foundation in which the Foundation is Not only does the Foundation Law apply but the Waqf Law also applies in which Act states that the recipient of the Waqf must carry out the Waqf in accordance with the original intent and purpose of granting Waqf this is in accordance with Act No. 16 of 2001 concerning the Jo Foundation, Act No. 28 of 2004 concerning Amendments to Act No. 16 of 2001 concerning Foundations Article 26 paragraph (3) which states that; "In the event that the wealth of the foundation comes from waqf, then the provisions of the law of waqf apply". Obstacles and Solutions Amendment to Foundation Articles of Association through a Notary for Foundation Assets from the Waqf Process is a legal consequence of a notary lawsuit can be sued to pay compensation, interest and fees. And the notarial deed has no legal force if it is not in accordance with the laws and regulations that apply to the foundation.

\section{References}

Journals:

[1] A.A Dalem Jagat Krisno,Ni Ketut Supasti Dharmawan., \& A.A. Sagung Wiratni Darmadi.(2016). "Akibat Hukum Yang Ditimbulkan Dari Wanprestasi Dalam Perjanjian Autentik Sewa-Menyewa Tanah", dalam Kertha Semaya Volume 4 No. 1. p. 2,

[2] Agus Toni Purnayasa. "Akibat Hukum Terdegradasinya Akta Notaris yang Tidak Memenuhi Syarat Pembuatan Akta Autentik", dalam Acta Comitas Jurnal Hukum Kenotariatan Vol.3 No. 3. P. 398,

[3] Avina Rismadewi, \& Anak Agung Sri Utari. "Kekuatan Hukum Dari Sebuah Akta Di Bawah Tangan", dalam Jurnal Hukum dan Pembangunan, Vol. 36 No. 4 (2006). 
[4] Febri Rahmadhani. "Kekuatan Pembuktian Akta di Bawah Tangan Waarmerking Dalam Perspektif Peraturan Perundang-undangan di Indonesia", in Jurnal Online Universitas Jambi, Vol. 2 No. 2 (2020).

[5] Ghita Aprillia Tulenan. "Kedudukan Dan Fungsi Akta Di Bawah Tangan Yang Dilegalisasi Notaris", in Jurnal Elektronik Bagian Hukum Administrasi Negara Fakultas Hukum Unsrat, Vol. 2, No. 2 (2014).

[6] Intan Ayu Widyowati. (2017) "Keberadaan Akta Notaris Terkait Proses Pemberesan Harta Pailit Berdasarkan Undangundang Nomor 37 Tahun 2004 Tentang Kepailitan Dan Penundaan Kewajiban Pembayaran Utang". Tesis Fakultas Hukum Universitas Islam Sultan Agung Semarang.

[7] Murni \& Abdul Gani. (2020) "Tanggung Jawab Hukum Kepada Pengurus Yayasan Terhadap Failednya Suatu Yayasan". dalam Jurnal Pionir LPPM Universitas Asahan Vol. 6 No. 1 (2020),

[8] Nur Azrani. (2010). "Peranan Notaris Terhadap Perubahan Anggaran Dasar Yayasan yang Berbadan Hukum Setelah Undang-Undang Nomor 28 Tahun 2004 Tentang Yayasan Di Tanjung Pinang Kepulauan Riau". Tesis Magister Kenotariatann, Program Pasca Sarjana Universitas Gadjah Mada Yogyakarta.

[9] Rahmad Hendra. "Tanggungjawab Notaris Terhadap Akta Otentik Yang Penghadapnya Mempergunakan Identitas Palsu Di Kota Pekanbaru". dalam Jurnal IImu Hukum Volume 3 No. 1. P. 4.

Books:

[1] Abdul Ghofur Anshori.(2009)."Lembaga Kenotariatan Indonesia, Perspektif Hukum dan Etika". Yogyakarta : UII Press.

[2] Ahmad Ali. (2009). "Menguak Teori Hukum (Legal Theory) dan Teori Peradilan (Judicialprudence) Termasuk Interpretasi Undang-Undang (Legisprudence), Volume 1Pemahaman Awal". Jakarta : Kencana.

[3] Ahmad Rofiq. (2004). Fiqh Kontekstual : Dari Normatif ke Pemaknaan Sosial, Cetakan Pertama, Yogyakarta : Pustaka Pelajar.

[4] Charlie Rudyat. (2013). "Kamus Hukum". Indonesia : Pustaka Mahardika.

[5] G.H.S. Luban Tobing. (1990). "Peraturan Jabatan Notaris". Jakarta : Erlangga. p. 61. Tim Penyusun Kamus Pusat Pembinaan dan Pengembangan Bahasa (1990) "Kamus Besar Bahasa Indonesia". Cetakan ketiga, Jakarta: Balai Pustaka.

[6] Habib Adjie. (2015). "Penafsiran Tematik Hukum Notaris Indonesia, Berdasarkan Undang-Undang Nomor 2 Tahun 2014 Tentang Perubahan Atas Undang-Undang Nomor 30 Tahun 2004 Tentang Jabatan Notaris". Bandung : PT. Refika Aditama.

[7] M. Luthfan Hadi Darus. (2017). "Hukum Notariat dan Tanggung Jawab Jabatan Notaris". Yogyakarta : UII Press. 
[8] (2015). "Yayasan, periodisasi dalam pembuatan akta, malpraktek dalam pembuatan akta". Yogyakarta : Cakrawala Media.

[9] ............. (2016). "Legal Standing". Yogyakarta : Cakrawala Media.

[10] Ngadino. (2019)."Tugas dan Tanggung Jawab Jabatan Notaris Indonesia". Semarang : UPT Penerbitan Universitas PGRI Semarang Press.

[11] Peter Mahmud Marzuki. (2006). "Penelitian Hukum, Second Edition". Jakarta : Kencana Prenada Media Group.

[12] R. Murjiyanto. (2011). "Badan Hukum Yayasan, Aspek Pendirian dan Tanggungjawab". Yogyakarta : Liberty.

[13] Ronny Hanitijo Soemitro,. (1988). "Metodologi Penelitian Hukum". Jakarta : Ghalia Indonesia.

[14] Rudhi Prasetya. (2012). "Yayasan Dalam Teori Dan Praktik". Jakarta : Sinar Grafika.

[15] Sahat HMT Sinaga. (2019) "Notaris \& Badan Hukum Indonesia". Bekasi : Jala Permata Aksara.

[16] Salim HS. (2010). "Perkembangan Teori Dalam IImu Hukum". Jakarta : Rajawali Pers.

[17] . (2011). Perancangan Kontrak \& Memorandum Of Understanding (MOU). Jakarta : Sinar Grafika.

[18] Shidarta. (2006). "Moralitas Profesi Hukum Suatu Tawaran Kerangka Berfikir". Bandung : PT. Revika Aditama.

[19] SiahKhosyi'ah. (2010) "Wakaf dan Hibah Perspektif Ulama Fiqh dan Perkembangannya dilndonesia". Bandung : CV Pustaka Setia.

[20] Soegianto. (2015). "Etika Profesi dan Perlindungan Hukum Bagi Notaris". Yogyakarta : Farisma Indonesia.

[21] Soejono Soekanto. (2010). "Pengantar Penelitian Hukum", Jakarta : UI Press.

[22] Subekti \&Mulyoto. (2011) Yayasan Sebelum dan Sesudah Berlakunya Undang-Undang Yayasan dan PP. No. 63 Tahun 2008. Yogyakarta : Cakrawala Media.

[23] Widhi Handoko. (2019)."Dominasi Negara Terhadap Profesi Notaris Antara Ide Dan Realitas". Bogor : PT Roda Publikasi Kreasi.

Regulation:

[1] Act No. 2 of 2014 concerning Amendments to Act No. 30 of 2004 concerning the Position of a Notary.

[2] Compilation of Islamic Law (KHI).

[3] The Civil Code, Burgerlijk Wetboek Voor Indonesie, Staatsblad Year 1847 Number 23.

[4] The Commercial Code (KUHD)

[5] The Criminal Code, Number 1 of 1946, State Gazette of the Republic of Indonesia of 1915 Number 732 
